\title{
Effect of antibiotic misuse on the emergence of microbial resistance among urologic patients
}

\author{
Maimonah Qasim Yahya*, Salah Hamad Azba**, Maali Ibrahim Younus Al-Hayali** \\ *Department of Clinical Laboratory Science, College of Pharmacy, Mosul University/Mosul/Iraq. \\ ** Al-Jamhory Teaching Hospital, Mosul, Iraq. \\ Email: pharm.maymona@uomosul.edu.iq
}

$\stackrel{\text { Received }}{\text { 04-06-2021 }} \quad \underline{\text { Accepted }}$

ABSTRACT

Background: The study aimed to identify the types of bacteria isolated from the urine of patients with urinary tract infections focusing on the resistant isolates then comparing the results with the types of antibiotics misused by those patients in order to suggest some measures to mitigate the increasing rates of antibiotic resistance. Material and Methods: Urine samples were collected from patients aged from 10 to 60 years old who visited Al-Jomhory Hospital in Mosul City/Nineveh Governorate during a period between February and May 2021. Bacterial culture, identification, and antimicrobial susceptibility testing against different antibiotics were performed by Kirby Bauer's disc diffusion method and the results were compared with patient medical history of antibiotic use without consulting a physician. Results: Overall, 7 different bacterial pathogens were identified, 5 gram-negative and 2 gram-positive bacteria. The majority of bacterial pathogens isolated was Escherichia coli 37.6\%, followed by Klebsiella spp. 35.5\%. It is worth noting that the most effective drug was quinolone $(\mathrm{P} \leq 0.05)$ on bacterial species with least effective was penicillins worrisome results was the isolation of a high percentage of Pseudomonas aeruginosa, that was resistant to all antibiotics used in this research, by contrast, a high percentage of Enterococcus faecalis was sensitive to those antibiotics. Conclusion: The study revealed that a higher percentage of resistant bacteria were isolated in patients with a medical history of antibiotics misuse which might change drug prescribtion line in a hospitalized patients with bacterial infections.

Keywords: Bacterial pathogen, antibiotic resistance, urinary tract infection.

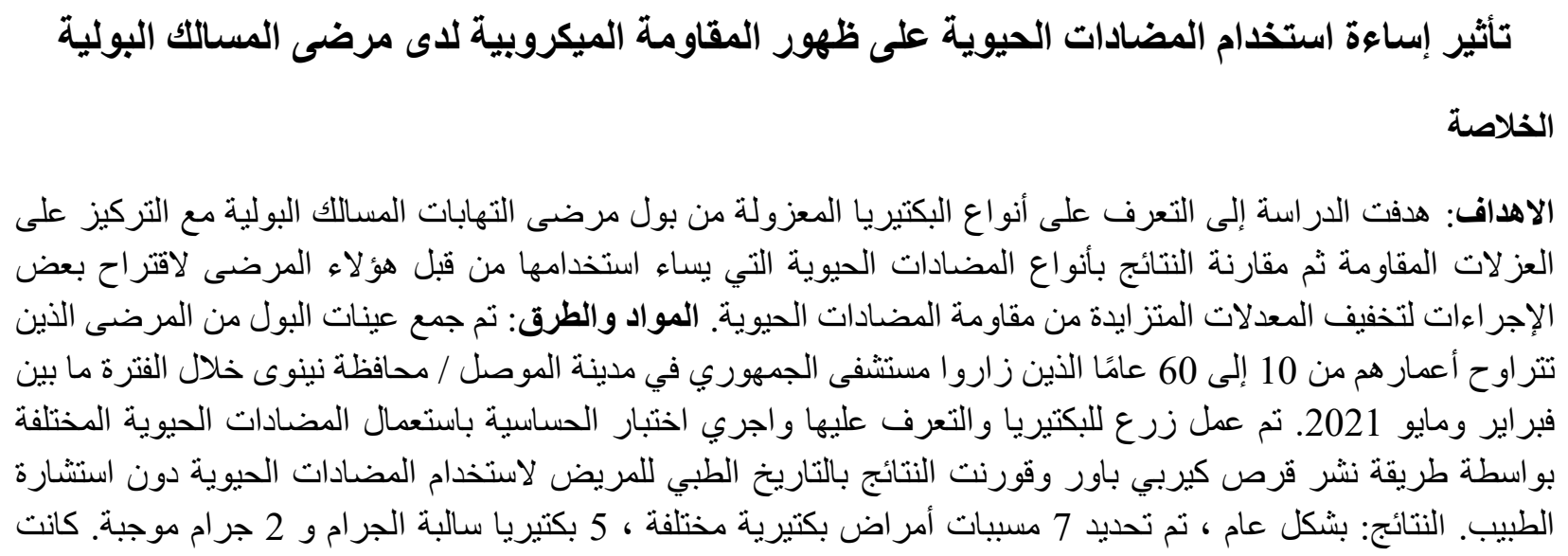




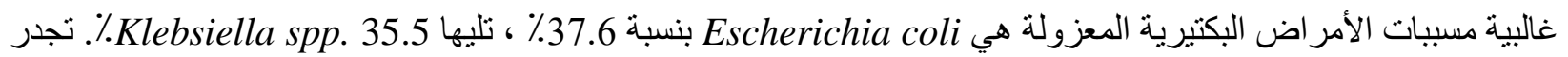
الاشارة الى أن عقار الكينولون كان أكثر الأدوية فعالية (P

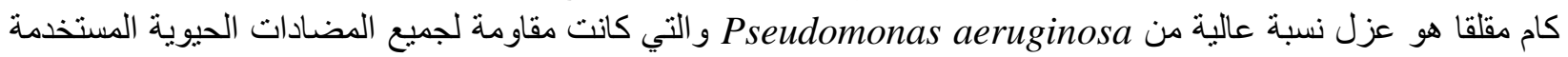

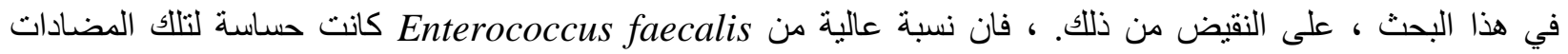

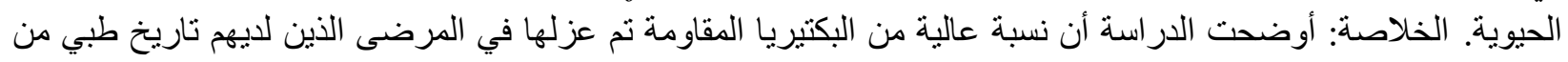
سوء استخدام المضادات الحيوية مما قد يغير خط وصف الأدوية في المرضى الذين يعانون من عدوى بكثيرية. الكلمات المفتاحية: مسبيات الأمر اض البكتيرية ، مقاومة المضادات الحيوية ، التهابات المسالك البولية.

\section{Introduction}

S ince the discovery of penicillin in 1928, antibiotics are used clinically and have influential means in fighting bacterial infections, but this did not last long due to the emergence of bacterial resistance 1 . In fact, the resistance is spreading rapidly around the world, compromising the effectiveness of antibiotics and affecting the health of millions of people ${ }^{2}$. In 2015, the World Health Organization launched a global campaign called "World Antibiotic Awareness Week" to raise awareness of the dangers of antibiotic misuse and of how these antibiotics are used, emphasizing the importance of prescribing them by doctors ${ }^{3}$. Scientists claimed that improper antibiotic usage, such as dispensing antibiotics without a prescription or failing to follow the treatment protocol, caused a decline in efficacy of antibiotics with development of bacterial resistance ${ }^{2}$. Generally antibiotics are used for killing or preventing the reproduction of pathogens, however their overuse or abuse, as well as insufficient manufacturing of a new pharmaceutical generations, has become a catastrophic crisis worldwide due to the emergence of a microbial resistance as well as loss of their antibacterial benefit in the recent years ${ }^{2}$. Bacteria are the most common cause of UTI, sometimes fungi and viruses could be involved especially among immunecompromized patients 1. Each bacterium has resistance to an antibiotic class according to its structure and composition, Whatever the source of resistance, these properties are present in many bacteria in nature ${ }^{4}$.

Urinary tract infections caused clinical and societal consequences for the patients, but their bacteriological characteristics vary with different factors. Urine culture is still considered as the main criterion for urinalysis; which usually provide an accurate diagnosis ${ }^{5}$. The invasion of the urinary tract tissue with a foreign microorganisms in usually referred to as urinary tract infection (UTI), the infection could be asymptomatic, mild symptomatic or developed into a complicated infection ${ }^{6}$.

In developing countries, infections are the leading cause of death. This is primarily due to the emergence of newer infectious species, in addition to the emergence of antimicrobial resistance. Bacteria have become smarter over time, together with the overuse of antibiotics have resulted in bacterial resistance to antimicrobial agents, and this has been identified as a major issue in the treatment 
of microbial infections ${ }^{7}$. Examples of bacterial biochemical resistance mechanisms include antibiotic inactivation, target modification, altered permeability, as well as metabolic pathway ${ }^{8}$. Thus laboratory examinations are performed to choose the desired antibiotic, in addition to clinical examination regarding patient's age, tolerance, and immune system status ${ }^{8}$. Indeed, the World Health Organization (WHO) has predicted that by 2050, will result in the deaths of 10,000,000 people per year due to the development of bacterial resistance to commercially available antibiotics 9 .

Antibiotics use by patients in selfmedication without clinical prescription is considered the major risk factor for developing antibiotic resistance, which is a common. In addition, most patients do not finish the entire course of antibiotics prescribed whenever they improvment.On the other hand, the use of antibiotics for viral infections diseases would also increase antibiotic resistance rates ${ }^{9}$. Thus, this study is important for clinicians to prescribe optimum antibiotics against the isolated bacteria, as well as avoide overprescribing unnecessary antibiotics without special need. Such data could also assist authorities to regulate certain policies for an antibiotic prescription.

Therefore, this research primarily aimed to identify the types of bacteria isolated from the urine of patients with urinary tract infections focusing on the resistant isolates then comparing the results with the types of antibiotics misused by those patients in order to suggest some measures to mitigate the increasing rates of antibiotic resistance.

\section{Material and methods}

\section{Bacterial isolates}

In this cross section study, we focused on bacterial isolated from patients suffering from urinary tract infections (UTIs). A total of 270 non-repeat clinical urine samples were collected from inpatient and outpatient, with or without clinical symptoms, at Al-Jomhory Hospital in Mosul City/ Nineveh Governorate during the period from February 2021 to May 2021. Samples were collected with clear instructions to the participants to collect the midstream urine after vulva swabbing with clean water. This technique is used for sampling purposes. Voluntary consent was obtained from patients to participate in the study. Clean catch urine specimens were collected from each of the 270 study patients aged between 10-60 years, the sample was transferred to the Microbiology Laboratory at the College of Pharmacy / University of Mosul within one hour of collection. Processing of the specimen was done under set standards for obtaining best results. Each sample was subjected to urine microscopy, culture, set of standard biochemical and microbiological tests, and sensitivity tests, to determine the microorganisms involved and their antibiotics sensitivity pattern 10 . Isolates were kept in semisolid Trypticase soy broth stock and stored at $4^{\circ} \mathrm{C}$ until further use. As well as the information regarding the names of the antibiotics used by patient and the frequency of usage were collected in the form of questionnaires, 
interviews or from previous prescriptions that the patient reused it without obtaining the doctor's approval to repeat its use. All results have been collected as database for further analysis.

\section{Antibiotic susceptibility testing}

Susceptibility testing was performed by disc diffusion method using antimicrobial reagents that diffuse into the medium, inhibiting the microorganism replication on the surface of a solid medium. Disks are a commercially available for the routinely used antibiotics. The National Committee for Clinical Laboratory Standards (NCCLS) methods and criteria were used for evaluation and determination of the antibiotic susceptibility test by using ordinary described antibiotics discs (Maxicare Medical Laboratory, Lagos, riNigea) 10,11 . The standardized disc diffusion method was adopted to evaluate the effect of different types of antibiotics on different bacteria isolated before. Briefly, all bacteria isolated from 270 urine samples were subculture on nutrient agar and incubated aerobically at $37^{\circ} \mathrm{C}$ for $24 \mathrm{~h}$, the inoculum was prepared at a concentration of $108 \mathrm{CFU} / \mathrm{ml}$ by picking 3-5 colonies of each isolated bacteria into 3-5 ml Muller-Hinton broth, adjust the turbidity of a bacterial suspension to 0.5 MacFarland standard visually, fresh bacteria was wiped homogeneously on the surface of MullerHinton agar using sterile swab under aseptic conditions, Allow 5-10 minutes for the agar to dry, allowing the bacteria to establish themselves on the media, then place the appropriate commercially available antibiotic discs on the inoculated agar plate then incubated at $37{ }^{\circ} \mathrm{C}$ for $24 \mathrm{~h}$. The following antibiotic discs were tested, Amoxicillin + Clavulanic acid, Penicillin, Cefotaxime, Ceftriaxone, Amikacin, Gentamycin, Ciprofloxacin, Nalidixic acid, Imipenem, and Meropenem. Areas of inhibition were measured around each disc. The experiment was conducted in triplicate to calculate the mean area diameter for each antibiotic disc and the antibiotic susceptibility against bacteria was estimated by applying the zone size interpretation chart to evaluate bacteria sensitivity on the selected antibiotics.

People who misuse antibiotics were identified in three ways: they either repeat the use of old prescriptions without consulting a doctor, or they buy antibiotics without a prescription, which is a common practice in self-treatment, and finally, the majority of people do not complete the full course of prescribed antibiotics.

\section{Ethical consideration}

All ethical considerations and obligations were duly addressed, the study was conducted after approval of the University Committee for Ethics of Medical Researches and the approval of the Scientific and Ethical Research Committee at the Nineveh Health Department. Before collecting data, participants provided written informed consent. They were given the option of refusing the participation in the study and parental consent was obtained for minor children. All data obtained from participants were coded with confidence. 
Participants who were positive for bacterial test, were informed by the physcian and they started receiving appropriate treatment.

\section{Statistical analysis}

All experiments have been performed three times in the present research. Data analysis was performed using SPSS statistic package(version 19) of the means, percentages, and chi-square analysis were used for data group analysis. All differences were statistically considered significant at $\mathrm{P} \leq 0.05$.

\section{Results}

Clinical urine samples of 270 persons age group (10-60 years) of both sexes were analyzed for culture and sensitivity testing of, 174 females (64.4\%)and 96 males $(35.6 \%)$ were processed. A total of 170 patients $(62.96 \%)$ had at least one bacterial pathogen, eight of which $(2.96 \%)$ had polymicrobial pathogen and $100(37.03 \%)$ cases with no bacterial pathogens isolated, thus culture positivity $62.96 \%$. In our study, there was a higher prevalence of urinary infections among females, $92(54.12 \%)$ and $78(45.88 \%)$ males were infected. The highest level was between 21-30 years of people followed by those aged 31-40. This means that the large incidence of infection was in the period between 20-40 years as summarized in table-1.

Table (1): Distribution of urinary tract infections according to age and gender.

\begin{tabular}{|c|c|c|c|}
\hline $\begin{array}{l}\text { Age } \\
\text { group }\end{array}$ & \multicolumn{2}{|c|}{ Infected patients $(\%)$} & \multirow[b]{2}{*}{ Total } \\
\hline Years & Males & Females & \\
\hline 20-Oct & $7(4.12 \%)$ & $6(3.53 \%)$ & 13 (7.65\%) \\
\hline $21-30$ & $20(11.76 \%)$ & $31(18.24 \%)$ & $51(30 \%)$ \\
\hline $31-40$ & $24(14.12 \%)$ & $26(15.29 \%)$ & 50 (29.41\%) \\
\hline $41-50$ & $18(10.59 \%)$ & $22(12.94 \%)$ & 40 (23.53\%) \\
\hline $51-60$ & $9(5.29 \%)$ & $7(4.12 \%)$ & 16 (9.41\%) \\
\hline Total & $78(45.88 \%)$ & $92(54.12 \%)$ & 170 (100\%) \\
\hline
\end{tabular}

Microbiological profile of our research show that seven different bacterial pathogens were isolated, five $(71 \%)$ gramnegative and two (29\%) gram-positive bacteria. It was worth noting that more than one type of bacteria was isolated from 8 people, bringing the number of isolated samples to 186 . It was demonstrated that $E$. coli accounted for the most common organism followed by Klebsiella spp. accounted the 2nd most common organism, then Acinetobacter spp. (7.53\%), Enterococcus faecalis (6.45\%), Pseudomonas spp. and Staph. aureus $(5.38 \%)$ with the least isolated microorganism was Neisseria gonorrhea $(2.15 \%)$ as represented in figure-1 


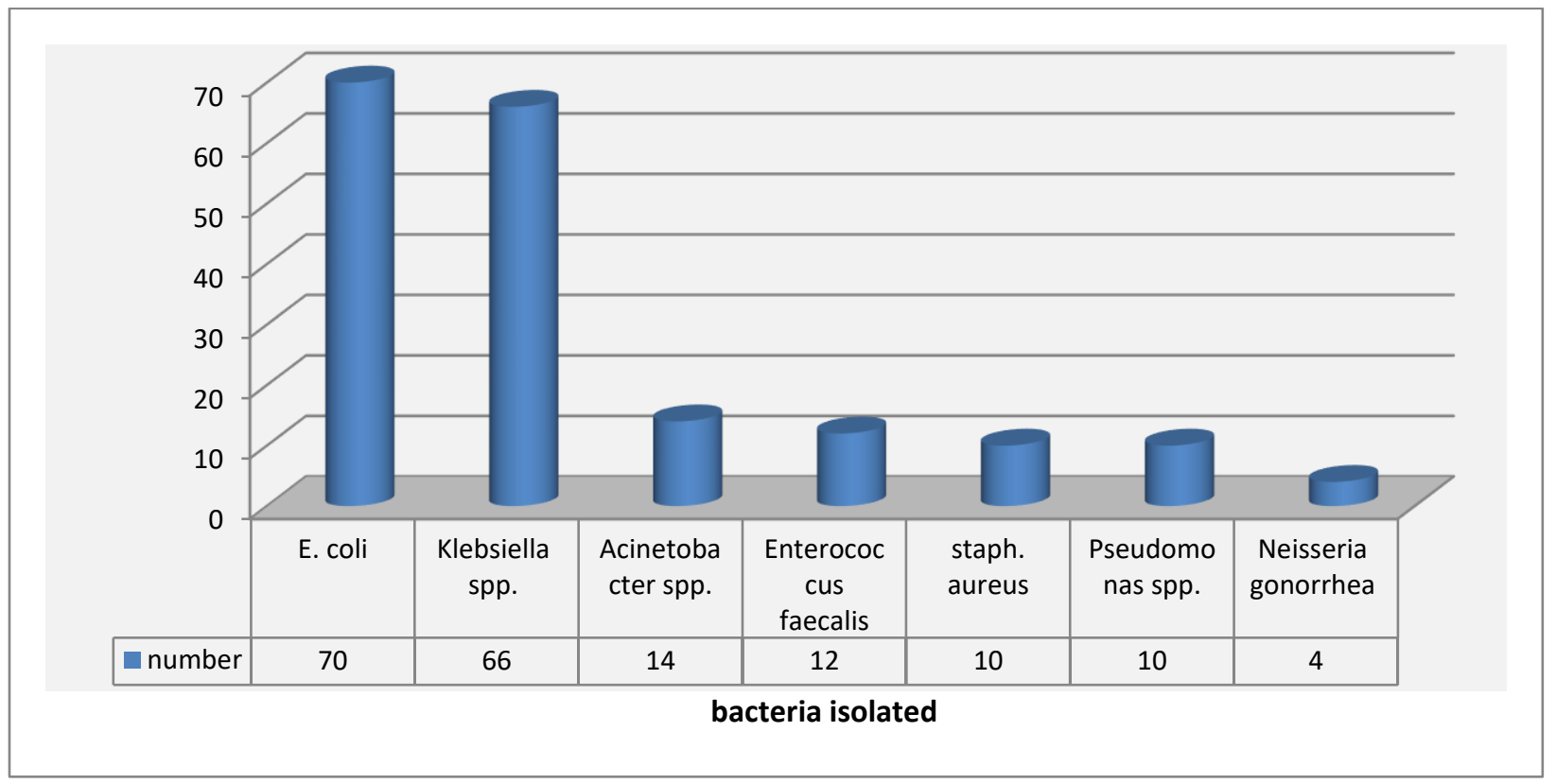

Figure (1): Distribution of bacteria among clinical isolates.

In our study group, females were predominantly-infected 92 versus 78 infected males, the predominant age of infection was between 20-30 years. The most common bacteria isolated from

\begin{tabular}{|c|c|c|c|c|c|c|c|c|c|c|c|c|c|c|c|}
\hline Age & \multicolumn{2}{|c|}{ E. coli } & \multicolumn{2}{|c|}{$\begin{array}{c}\text { Klebsiella } \\
\text { spp. }\end{array}$} & \multicolumn{2}{|c|}{$\begin{array}{c}\text { Acinetobacter } \\
\text { spp. }\end{array}$} & \multicolumn{2}{|c|}{$\begin{array}{c}\text { Enterococcus } \\
\text { faecalis }\end{array}$} & \multicolumn{2}{|c|}{$\begin{array}{c}\text { Pseudomonas } \\
\text { spp. }\end{array}$} & \multicolumn{2}{|c|}{$\begin{array}{l}\text { Staph. } \\
\text { aureus }\end{array}$} & \multicolumn{2}{|c|}{$\begin{array}{l}\text { Neisseria } \\
\text { gonorrhea }\end{array}$} & \multirow[t]{2}{*}{ Total } \\
\hline & $\mathrm{M}$ & $\mathrm{F}$ & $M$ & $F$ & $\mathrm{M}$ & $F$ & $\mathrm{M}$ & $\mathrm{F}$ & $\mathrm{M}$ & $F$ & $\mathrm{M}$ & $\mathrm{F}$ & $\mathrm{M}$ & $\mathrm{F}$ & \\
\hline $10-20$ & 0 & 1.075 & 3.226 & 1.075 & 1.075 & 0 & 0 & 1.075 & 0 & 0 & 0 & 0 & 0 & 0 & 7.527 \\
\hline $21-30$ & 6.452 & 8.602 & 3.226 & 6.452 & 0 & 0 & 1.075 & 3.226 & 1.075 & 0 & 0 & 0 & 0 & 0 & 30.11 \\
\hline $31-40$ & 5.376 & 4.301 & 7.527 & 6.452 & 0 & 0 & 0 & 0 & 0 & 0 & 0 & 3.226 & 1.075 & 1.075 & 29.03 \\
\hline $41-50$ & 2.151 & 4.301 & 1.075 & 3.226 & 3.226 & 3.226 & 0 & 0 & 2.151 & 2.151 & 2.151 & 0 & 0 & 0 & 23.66 \\
\hline $51-60$ & 3.226 & 2.15 & 1.075 & 2.151 & 0 & 0 & 1.075 & 0 & 0 & 0 & 0 & 0 & 0 & 0 & 9.678 \\
\hline SUM & 17.2 & 20.43 & 16.13 & 19.35 & 4.301 & 3.226 & 2.151 & 4.301 & 3.226 & 2.151 & 2.151 & 3.226 & 1.075 & 1.075 & 100 \\
\hline
\end{tabular}

In this research, we noticed a very large percentage of people misuse antibiotics, especially penicillins, cephalosporins $\quad(39.9 \%$ and $35.9 \%)$ patients' urine was E. coli and Klebsiella spp. $20.43 \%$ and $19.35 \%$ respectively, while the least common was Neisseria gonorrhea $1.075 \%$ as presented in table-2. Table (2): percentage of bacterial distribution among patients according to sex and age. 


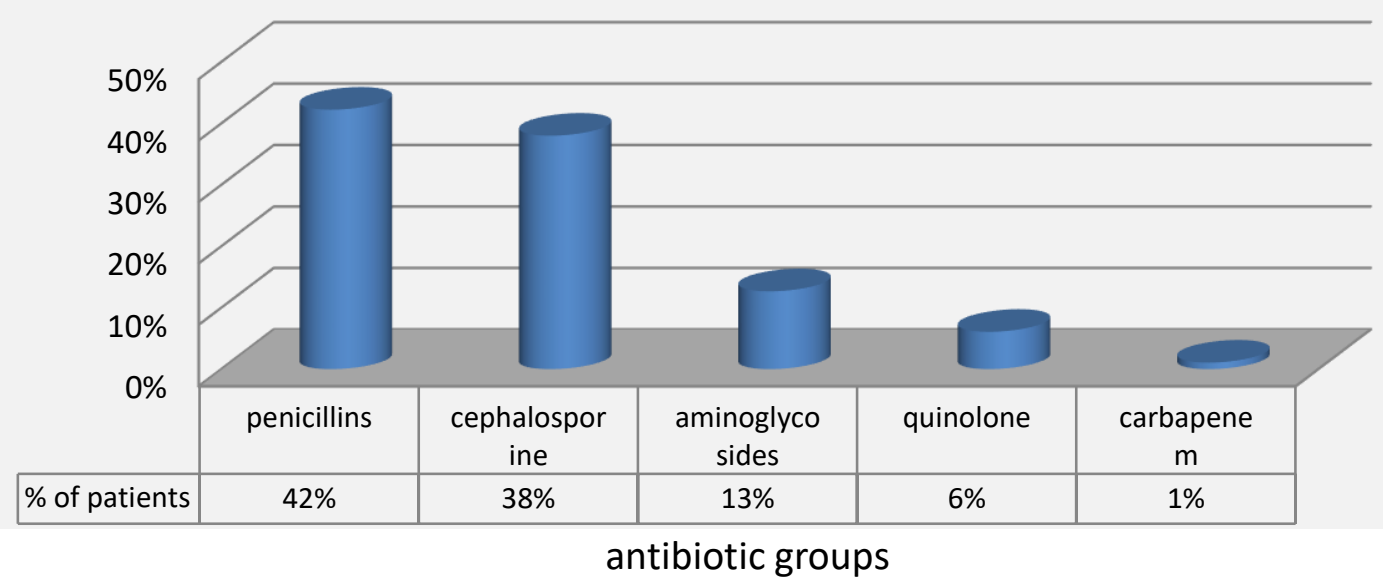

Figure(2): Percentage of antibiotic misuse among patients

The standardized disc diffusion method was adopted to evaluate the effect of different types of antibiotics on different bacteria isolated before. Two antibiotics were used to represent their group as summarized in table- 3 .

Table (3): List of antibiotics used in disc diffusion method for representing their groups.

\begin{tabular}{|c|c|c|c|c|}
\hline $\begin{array}{c}\text { antibiotic } \\
\text { groups }\end{array}$ & antibiotic disc & $\begin{array}{c}\text { concentration } \\
\text { (ug/ disc) }\end{array}$ & antibiotic disc & $\begin{array}{c}\text { concentration } \\
\text { ( ug/ disc) }\end{array}$ \\
\hline penicillins & $\begin{array}{c}\text { Amoxicillin }+ \\
\text { Clavulanic acid } \\
\text { (AMC) }\end{array}$ & 30 & Penicillin (P) & 10 \\
\hline cephalosporine & Cefotaxime (CTX) & 30 & Ceftriaxone (CRO) & 30 \\
\hline aminoglycosides & Amikacin (AK) & 30 & Gentamycin (CN) & 10 \\
\hline quinolone & Ciprofloxacin (CIP) & 5 & Nalidixic acid(NA) & 30 \\
\hline carbapenem & Imipenem (IPE) & 10 & Meropenem (MEM) & 10 \\
\hline
\end{tabular}

The antimicrobial susceptibility pattern of the different bacterial isolates to different antimicrobials is shown in Table-4. Drug sensitivity patterns reveal that grampositive bacteria have a higher sensitivity pattern than gram-negative bacteria. Isolated E. coli, Klebsiella spp., Acinetobacter spp., and pseudomonas aeroginosa show high resistance against penicillins, cephalosporine respectively, on the other hand, all isolated bacteria except pseudomonas aeroginosa show sensitivity to aminoglycosides and quinolone. 
Table (4): Antimicrobial sensitivity pattern of clinically isolated bacterial pathogens.

\begin{tabular}{|c|c|c|c|c|c|c|c|c|c|c|}
\hline \multirow{2}{*}{ Bacteria Isolated } & \multicolumn{9}{|c|}{ Antibiotics Groups } \\
\cline { 2 - 14 } & \multicolumn{2}{|c|}{ penicillins } & \multicolumn{1}{|c|}{ cephalosporine } & \multicolumn{2}{c|}{ aminoglycosides } & \multicolumn{2}{|c|}{ quinolone } & \multicolumn{2}{c|}{ carbapenem } \\
\cline { 2 - 14 }$y$ & $\mathrm{R}$ & $\mathrm{S}$ & $\mathrm{R}$ & $\mathrm{S}$ & $\mathrm{R}$ & $\mathrm{S}$ & $\mathrm{R}$ & $\mathrm{S}$ & $\mathrm{R}$ & $\mathrm{S}$ \\
\hline E. Coli & 91.49 & 8.5 & 73.85 & 26.15 & 36.92 & 63.08 & 11.86 & 88.14 & 30.72 & 69.28 \\
\hline Klebsiella spp. & 93.56 & 6.44 & 81.53 & 18.47 & 50.058 & 49.942 & 20.15 & 79.85 & 57.26 & 42.74 \\
\hline Acinetobacter & 97.14 & 2.86 & 85.87 & 14.13 & 72.43 & 27.67 & 13.31 & 86.69 & 14.61 & 85.39 \\
\hline $\begin{array}{c}\text { Enterococcus } \\
\text { faecalis }\end{array}$ & 47.24 & 52,76 & 29.46 & 70.54 & 12 & 88 & 4 & 96 & 11.77 & 88.23 \\
\hline $\begin{array}{c}\text { pseudomonas } \\
\text { aeroginosa }\end{array}$ & 61.54 & 38.46 & 83.33 & 16.67 & 53.12 & 46.88 & 66.88 & 33.12 & 60.94 & 39.06 \\
\hline Staph aureus & 67.74 & 32.26 & 28.6 & 71.4 & 32.26 & 67.74 & 16.47 & 83.53 & 8.33 & 91.67 \\
\hline chi-square & 157.1019 & 5.48 & 131.0451 & 23.12245 & 65.53165 & 84.28155 & 19.90909 & 132.5168 & 95.73239 & 74.35135 \\
\hline
\end{tabular}

R: resistance, S: sensitive

It is worth noting that the significant best effective drug was quinolone at $\mathrm{P} \leq 0.05$ and penicillins were the least effective. Quinolone and carbapenem showed a significant $\mathrm{P} \leq 0.05$ highest inhibitory effect on the diagnosed bacterial species, compared to the rest of the antibiotics used except for pseudomonas aeroginosa that showed resistance to all antibiotics used in this research. They were regarded as the most common sensitive drugs for E. coli, Klebsiella spp. Acinetobacter spp., Enterococcus faecalis, and staph. aureus. What was worrisome was that a high percentage of Pseudomonas aeruginosa showed resistance to all antibiotics used, on the other hand, a higher percentage of Enterococcus faecalis were sensitive to the same antibiotics used as shown in figure-3.

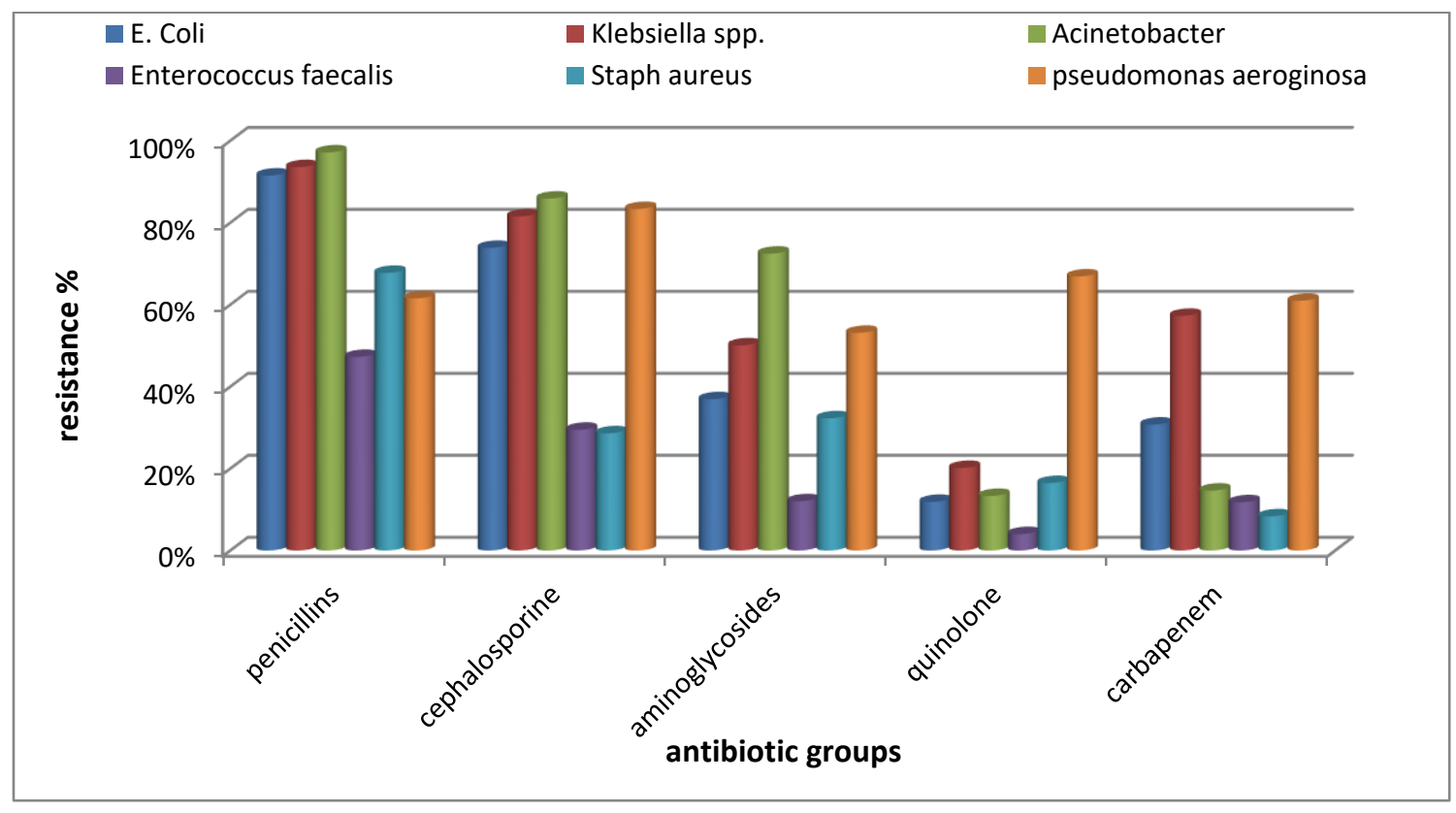




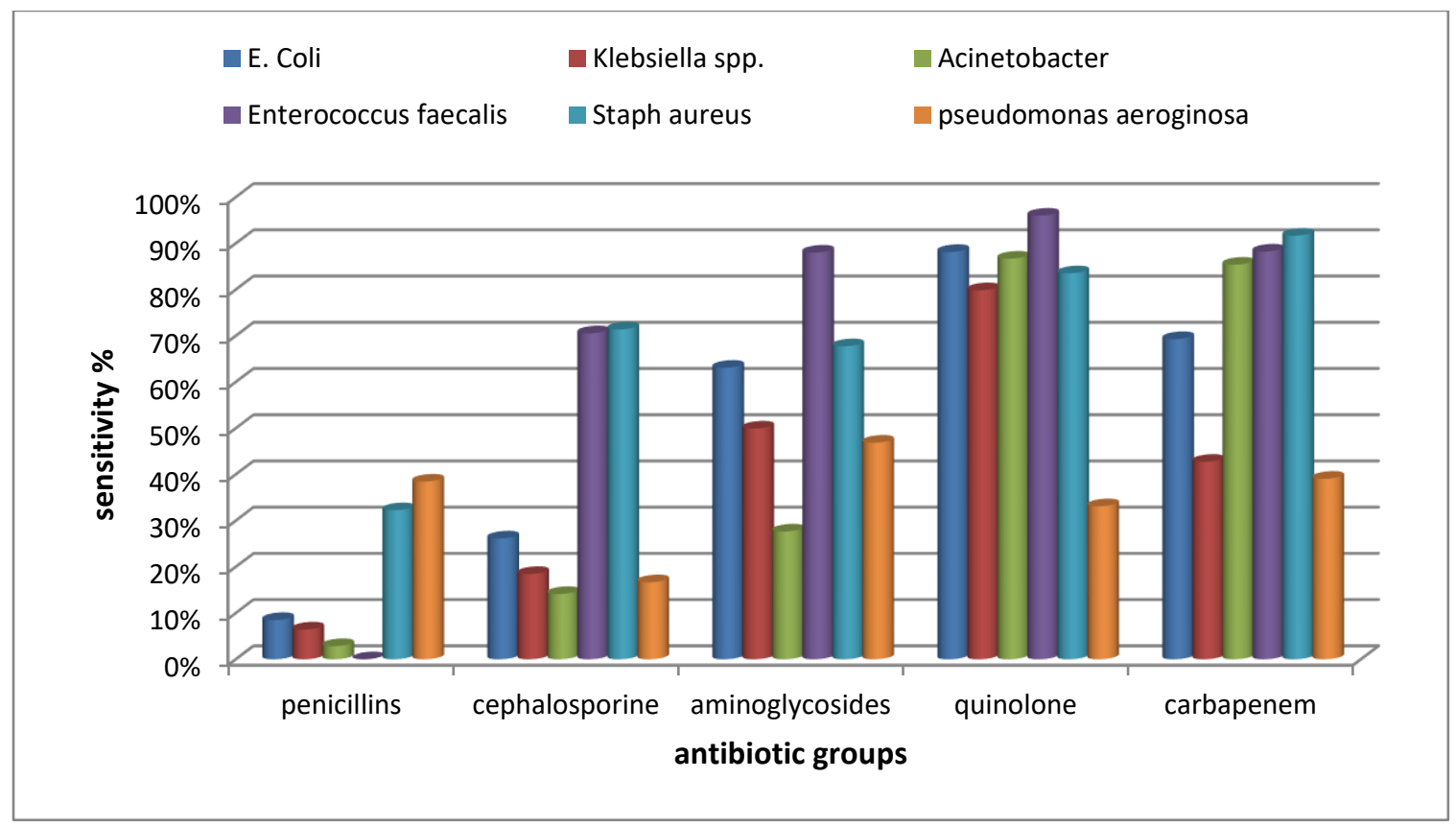

B

Figure (3): Overall Antimicrobial susceptibility pattern of the isolated bacterial pathogens. A: bacterial resistance to antibiotics, B: bacterial sensitivity to antibiotics.

\section{Discussion}

The exceptional conditions in Iraq over the last four decades significantly affected the absence of exact studies that evaluate the extent of antibiotic abuse and the prevalence of antibiotic-resistant bacteria with consider to the low level of authoritative surveillance in various aspects of life - including those related to restricted antibiotic dispensing without prescription. The World Health Organization (WHO), in addition to the CDC's and the European Center for Disease Prevention's warnings, have shown on numerous occasions that there is mounting evidence of a steady increase in the number of bacterial infections resistant to currently available antibiotics. Each of these specialized agencies has proven beyond a shadow of a doubt that bacterial resistance to antibiotics is a real threat to human health ${ }^{9}$.

This research showed a high incidence of UTI among females 92 $(54.12 \%)$ than the males $78(45.88 \%)$ which may be due to anatomic and physical factors related to females, this was similar to the established data by Bonkat et al.2018 ${ }^{12}$ and Bazzaz et al. $2021^{13}$. Furthermore, the results revealed that the majority of infection was in the younger age group. The age distribution of patients in this study was consistent with those in other studies as Alsohaili et al.2015 ${ }^{14}$ and Storme et al. $2019^{15}$. This study showed that the most uropathogenic isolates were Escherichia coli $(37.36 \%)$ that was coming agree with that of Alsohaili et al. $2015^{14}$, Mattoo et al. $2021^{16}$, and Shrestha et al. 2021 ${ }^{17}$, followed by Klebsiella spp. (35.48\%), that agree with 
Madhi et al. $2018{ }^{18}$ but Overwhelming antibiotic use poses a serious challenge today to public health policymakers around the world. In fact, several experimental studies have identified increasing antibiotic use as a major contributor to communityacquired antibiotic resistance, especially in middle- and low-income countries. Epidemiologically, many studies suggest a direct relevance between antibiotic consumption and the evolution and spread of resistant bacteria strains ${ }^{19}$. Similarly our study revealed a higher percentage of isolates were resistant to the commonly used antibiotics, such results were consistent with those obtained by other studies (Alsohaili et al. $2015^{14}$ and Shrestha et al. $2021^{17}$, on the other hand, it is different from previous studies that showed a moderate level of resistance against these antibiotics which indicate the development of resistance during years (Santo et al. $2001^{20}$ and Sahm, et al. 2017 ${ }^{21}$ ). Quinolone and carbapenem antibiotic had an inhibitory effect on all isolated bacterial species except for Pseudomonas aeruginosa. In fact, Pseudomonas aeruginosa was resistant to all antibiotics used in this study, by contrast, Enterococcus faecalis was sensitive to the same antibiotics. When comparing these results with the percentage of commonly abused antibiotics among people, we find that have the largest percentage of resistance compared to quinolone and carbapenem (6\% and $1 \%$ respectively). That is why we focus on reducing excessive use of antibiotics without the actual need for them.

Antibiotics overused or overprescribed worldwide lead to the removal of bacterial drug-sensitive competitors, such resistance bacteria will be even augmented by natural reproduction ${ }^{2,22}$. This suggests that these bacteria are capable of transferring resistance traits to other organisms. Furthermore, patient expectations, a lack of education, poor medicine quality, unsanitary conditions that promote the spread of resistant bacteria, in addition, political corruption and insufficient monitoring are factors that must be addressed to reform health care ${ }^{23}$. Many strategies exist to help reduce such abuse and the spread of bacterial resistance. This involves using antibiotic prophylaxis selectively in patients with high-grade vesicoureteral reflux and hydronephrosis, as well as counseling about the value of compliance; treat with antibiotics when necessary depending on urine testing, and tailoring broad-spectrum treatment as needed. Formerly, some antibiotics were preferred as initial agents for empiric therapy of specific bacteria due to their high bacteriological and clinical cure rates, as well as low resistance rates among the most common pathogens ${ }^{24}$. The non-regulated practice of prescribing antibiotics, and noncompliance with laws in many countries contribute to the over-use of antibiotics. Finally, these suggestions should not be used in place of seeing a doctor, who is primarily concerned with diagnosing the condition and prescribing the appropriate medication. It is worth noting that in many countries, it is not possible to obtain antibiotics from pharmacies without a prescription by a doctor licensed to practice or a recognized hospital. 


\section{Conclusion}

The study revealed that a higher percentage of resistant bacteria were isolated in patients with a medical history of antibiotics misuse which might change drug prescribtion line in a hospitalized patients with bacterial infections.

\section{References:}

1- Khalifa AYZ. Scanning electron microscopy and antibiotic sensitivity of the actinobacterium, Kocuria sediminis DDK6. Journal of Applied Biology \& Biotechnology. 2017;5(03): 018-022.DOI: 10.7324/JABB.2017.50304.

2- Ventola CL. The antibiotic resistance crisis: part 1: causes and threats. Pharmacy and therapeutics. 2015 Apr;40(4):277-283.

3- Goff DA, Mendelson M. Putting your money where your mouth is: Scotland's attack on MRSA pays off. The Lancet Infectious Diseases. 2015 Dec 1;15(12):1369-70.

4- Perry, C., \& Hall, C. Antibiotic resistance: how it arises, the current position and future strategies. Benefits, 2017; 10, 32.

5- Lee KW, Song HY, Kim YH. The microbiome in urological diseases. Investigative and Clinical Urology. 2020 Jul;61(4):338. DOI: 10.4111/icu.2020.61.4.338.

6- Behzadi P, Behzadi E, Yazdanbod H, Aghapour R, Cheshmeh MA, Omran DS. A survey on urinary tract infections associated with the three most common uropathogenic

\section{Acknowledgment}

The authors thank the College of Pharmacy/University of Mosul and the administration of Al-Jumhuriya Teaching Hospital/Nineveh Health Department for the facilities provided to accomplish this work.

bacteria. $\quad$ Maedica. 2010 Apr;5(2):111.

7- Okeke IN, Nicolle LE. Factors contributing to the emergence of resistance. InThe Resistance Phenomenon in Microbes and Infectious Disease Vectors: Implications for Human Health and Strategies for ContainmentWorkshop Summary 2003 (pp. 132139).

8- Kapoor G, Saigal S, Elongavan A. Action and resistance mechanisms of antibiotics: A guide for clinicians. Journal of anaesthesiology, clinical pharmacology. 2017 Jul;33(3):300. DOI: 10.4103/joacp.JOACP_349_15.

9- Al-Zidan R, Abdulrazzaq G, AlShakarchi W. Antibiotic misuse and the development of bacterial resistance: Are we losing the battle?. Iraqi Journal of Pharmacy. 2019 Jul 1;16(1):73-84.

DOI: 10.33899/iphr.2019.165710.

10-Julia A. Kiehlbauch,1 George E. Hannett,1 Max Salfinger,1,2, Wendy Archinal,1 Catherine Monserrat, 1,3, $\dagger$ and Cynthia Carlyn. Use of the National Committee for Clinical Laboratory Standards Guidelines for Disc Diffusion 
Susceptibility Testing in New York State Laboratories. J Clin Microbiol. 2000 Sep; 38(9): 3341-3348. DOI: 10.1128/JCM.38.9.3341-3348.2000.

11-Wilkins TD, Holdeman LV, Abramson IJ, Moore WE. Standardized single-disc method for antibiotic susceptibility testing of anaerobic bacteria. Antimicrobial Agents and Chemotherapy. 1972 Jun 1;1(6):451-9.

DOI: 10.1128/AAC.1.6.451.

12- Bonkat G, Pickard R, Bartoletti R, Bruyère $F$, Geerlings $S$, Wagenlehner F, Wullt B, Pradere B, Veeratterapillay R. Urological infections. Arnhem: European Association of Urology. 2018.

13-Bazzaz BS, Fork SD, Ahmadi R, Khameneh B. Deep insights into urinary tract infections and effective natural remedies. African Journal of Urology. $2021 \quad$ Dec;27(1):1-3. Doi:https://doi.org/10.1186/s12301020-00111-z.

14- Alsohaili SA, Alharahsheh $\mathrm{MH}$, Almshagbeh MA, Alkhawaldeh RA, ALkhawaldeh WM. Bacterial pathogen in urinary tract infection and antibiotic resistance patteern in Zaraqa-Jordan. European Scientific Journal. 2015 Apr 1;11(12).

15- Storme O, Tiran Saucedo J, GarciaMora A, Dehesa-Dávila M, Naber KG. Risk factors and predisposing conditions for urinary tract infection. Therapeutic advances in urology. 2019

Mar;11:1756287218814382.doi: https://doi.org/10.1177/17562872188 14382.

16- Mattoo TK, Shaikh N, Nelson CP. Contemporary Management of Urinary Tract Infection in Children. Pediatrics. 2021 Feb 1;147(2). DOI: https://doi.org/10.1542/peds.2020012138.

17-Shrestha G, Wei X, Hann K, Soe KT, Satyanarayana S, Siwakoti B, Bastakoti S, Mulmi R, Rana K, Lamichhane N. Bacterial Profile and Antibiotic Resistance among Cancer Patients with Urinary Tract Infection in a National Tertiary Cancer Hospital of Nepal. Tropical Medicine and Infectious Disease. 2021 Jun;6(2):49.DOI: https://doi.org/10.3390/tropicalmed6 020049.

18- Madhi F, Jung C, Timsit S, Levy C, Biscardi S, Lorrot M, Grimprel E, Hees L, Craiu I, Galerne A, Dubos F. Febrile urinary-tract infection due to extended-spectrum beta-lactamaseproducing Enterobacteriaceae in children: A French prospective multicenter study. PLoS One. 2018 Jan 25;13(1):e0190910. DOI: https://doi.org/10.1371/journal.pone. 0190910.

19-Zaman SB, Hussain MA, Nye R, Mehta V, Mamun KT, Hossain N. A review on antibiotic resistance: alarm bells are ringing. Cureus. 2017 Jun;9(6). doi: 10.7759/cureus.1403.

20-Sahm DF, Thornsberry C, Mayfield DC, Jones ME, Karlowsky JA. Multidrug-Resistant Urinary Tract Isolates of Escherichia coli: 
Prevalence and Patient Demographics in the United States in 2000. Antimicrobial agents and chemotherapy. $2001 \quad$ May 1;45(5):1402-6. DOI: 10.1128/AAC.45.5.1402-1406.2001.

21-Santo E, Salvador MM, Marin JM. Multidrug-resistant urinary tract isolates of Escherichia coli from Ribeirão Preto, São Paulo, Brazil. Brazilian Journal of Infectious Diseases. 2007 Dec;11(6):575-8. https://doi.org/10.1590/S1413$\underline{86702007000600010 .}$.

22-Read AF, Woods RJ. Antibiotic resistance management. Evol Med
Public Health 2014;2014(1):147. doi:10.1093/emph/eou024.

23-Surji KM. Antibiotics misuse and factors leading to its' abuse in Kurdistan region. J Health Med Nurs. 2016 Feb;24(0):20-7.

24- Tada Dharmishtha G1, Gandhi Paragi J2, Patel Kiran N3. A study on antibiotic related resistance in UTI patients: a comparison between community acquired and hospital acquired E.coli. National Journal of Community

Medicine.2012;3(2):255-258. 